\title{
The Life Experiences of Young Maori: Voices From Afar
}

\author{
Adreanne Ormond \\ Intenational Research Institute for Maori and Indigenous Education, The University of Auckland, New Zealand
}

\begin{abstract}
Societal relationships of dominant and minority societal groups show that the marginalised minority Societal group are not powerless victims of the dominant societal group. The societal groups are positioned within dynamic power relationships shaping their societal engagements. The dominant societal group silences the indigenous community experiences to advance the dominant societal group, by demeaning the minority societal group's societal and cultural knowledge. Minority societal group marginalisation is heard in the young voices of the indigenous community. The identity of the young is flavoured by local, national and global cultures. They articulate their marginalisation by interweaving dominant and minority discourses. Their voices speak of marginalisation in ways that are transferable to many minority and indigenous societal groups.
\end{abstract}

This story begins in an indigenous Maori community on the east coast of the North Island of New Zealand. This indigenous community is much like any other east coast Maori community. It features Maori cultural meeting houses, historic cultural sites of significance and ancient burial grounds. Societal amenities such as supermarkets, paved sidewalks, corner dairies, shopping malls, movie theatres and high schools are absent. Instead there is blue ocean, uninhabited white sandy beaches, green rolling farmland speckled with white sheep and black cattle and narrow one lane roads that are covered with loose metal stones. One local shop provides the community with vehicle fuel, mail, newspapers, basic milk and bread stores and serves as a point of informal communal meetings and conversation. I know these roads and coastline like the back of my own hand for this is my home community of Mahia Peninsula that I grew up in and take my identity from.

The voices and narratives contained within this paper represent the young Maori from my community and are based upon the postgraduate research that I carried out in a Marsden funded project with the theme 'Youth First - Taking Kids Talk Seriously'. The voices of these young Maori are moulded by societal circumstances specific to their geographic, societal location and age group (Smith et al., 2002). One of the societal circumstances that influences their voices is that as Maori they are the indigenous people of New Zealand and, therefore, by virtue of their ancestry and ethnicity they speak from a position of power. However, this power is tempered by their minority population status so that despite the confidence they resonate they concurrently echo their peripheral location within mainstream New Zealand society. This means that their voices are not taken seriously by the dominant societal group but are marginalised into silence by a society that legitimates voice according to the societal group from which it issues and what type of discourse it imbues and progresses. It is this process of voice legitimisation, narrative elitism and knowledge subjugation that this paper seeks to unravel.

Discourses of privilege, elitism, cultural oppression and knowledge subjugation provide ways to examine the processes that produce the young people's voices and silences. This means that in studying how voices are silenced we need to move beyond pathologising those who live on the margins. We must do more than participate in the cultural gaze of surveillance, pity, blame, or liberal hope (Fine, 1994).

A 'young people voices' focus introduces the notion that the relationship between the minority, dominant societal groups is not one of juxtaposition but is a societal process of engagement that refers to 'black surrogacy' (Morrison, 1993). Morrison's notion of 'black surrogacy' examines minority/dominant societal group relationships by arguing that particular white US literature derives a sense of place and belonging, racial and societal identity in relation to the African-American presence. In other words white United States (US) literature is defined through engaging with African-American culture.

Address for correspondence: Dr Adreanne Ormond, The University of Auckland, Nga Pae o Te Maramatanga, Waipapa Marae Complex, Private Bag 92019, Auckland 1142, New Zealand. E-mail: a.ormond@auckland.ac.nz 
American Africanism makes it possible to say and not say, to inscribe and erase, to escape and engage, to act out and act on, to historicise and render timeless. It provides a way of contemplating chaos and civilisation, desire and fear, and a mechanism for testing the problems and blessings of freedom ... What became transparent were the self-evident ways that Americans choose to talk about themselves through and within a sometimes allegorical, sometimes metaphorical, but always choked representation of an Africanist presence. (Morrison,1993, pp 7-17)

In the context of the young people voices and silences it is the societal and institutional minority/dominant societal group connectedness of Morrison's black surrogacy that this paper examines. This is illustrated in the way that mainstream New Zealand society duplicitously gains societal and economic power from the minority societal group while deflecting the connection between dominant societal group privilege and minority societal group knowledge subjugation (Fine, 1994). We must contextualise Morrison's 'black surrogacy' within a New Zealand setting. We must observe how minority/dominant societal group surrogacy or connectedness marginalises the young people voices by rendering narratives that dominate and oppress minority societal group knowledge.

This article examines minority/dominant societal group surrogacy by placing the young people voices and silences within a discourse of dominant and marginalised narratives. The dominant narrative is named the 'narrative of the outsider' and refers to the dominant societal group and the colonisation of minority societal group knowledge and life experiences. The marginalised narrative is named the indigenous community narrative' and refers to the young people's minority societal group life experiences and indigenous community knowledge. The outsider and indigenous community narrative provide a framework to observe the societal forces that produce the societal experiences that flavour the young people's voices or silences.

Although I align the narrative of the outsider with the dominant societal group and the indigenous community narrative with the minority societal group, these discourses are both dominant and marginal. This means that either minority or dominant societal group members can and do speak through them. However, although both societal groups can and do speak through either discourse the dominant societal group shapes both discourses so that they represent and protect their societal group interests more than the interests of the indigenous community and their young Maori people. Despite this, the young people remain porous to both dominant and marginal discourses and constantly mediate the cultural barriers of both dominant and minority societal groups. Their engagement with either discourse is complicated by the irony that it acts against them to imbue the dominant societal group yet their youthful identity is defined by their nonallegiance to either discourse.
The following section discusses both the outsider and indigenous community narratives by exploring the themes that are central to the young people voices. These themes speak to the young people's indigenous community and demonstrate how dominant mainstream societal perspectives capitalise upon their life experiences in ways that marginalise and silence their voices. These themes are: natural perfection and beautification, tranquillity, geographical isolation, individual isolation, traditional farming industry and cultural exoticness.

\section{Deconstructing Dominant and Marginilised Narratives}

\section{Theme of Natural Perfection and Beautification}

Both the indigenous community and outsider narratives speak to the natural, physical beauty of this area but a comparison of the two demonstrates the cultural differences in the two narratives. For example, the young people speak about the natural beauty and bounty of their community.

Elise: Lots of people come to Mahia for summer they say it's paradise, it's got beautiful beaches and not polluted either, and it's very pretty with lots of green trees. They call it paradise and I am proud to come from here.

Rodney: When people ask me where I'm from and I say 'Mahia' they're like 'fa' that's the awesome surf place.

Jason: Us Mahiasian's we like to give ... AO [I was facilitating young people conversations and $\mathrm{AO}$ is an abbreviation for Adreanne Ormond.] So if I'm unemployed and I don't have any food you'll give me some?

Jason: Yeah prob'ly, yeah everyone at Mahia is always willing to give even if they have nothing to give, and you can live off the land anyways.

Alex: Yeah like if we go to the beach and get some kinas then we just give some to everyone.

Jason: Yeah just go to the beach and get some food.

Their talk echoes with personalised cultural attribution to both land and sea. Their stories portray an inherited sense of belonging to the land. Their lived out experience names the beach as a provider for the people, a source of common bonding and a vehicle for passing on cultural concepts such as 'aroha' which is sharing, 'give some to everyone. The young people speak with a secure knowledge that the land and sea will sustain them even when the economic system lets them down, 'yeah just go to the beach and get some food'.

The indigenous community narrative reflects an historic, emotional and pragmatic relationship between community, land and sea. This relationship speaks to the connection between the physical environment, individual and family identity. Snow (1993, p. 4) writes, 'construct a shared group identity for the present through particularised meaning of the past'. The land and sea 
provide the connecting point that fuses their ethnicity, self concept and sense of belonging together.

$\begin{array}{ll}\text { AO: } & \begin{array}{l}\text { Do you think that at home Maori get a rough time } \\ \text { [be]cause they're Maori? }\end{array} \\ \text { Jason: } & \begin{array}{l}\text { Nah every one's Maori at home, it's Pakeha's that } \\ \text { get a rough time ... The pakehas get a rough time. } \\ \text { [The group laughs.] }\end{array} \\ \text { Alex: } & \text { The white boys ... They get a rough time. } \\ \text { Jason: } & \text { Craig and what's his name? } \\ \text { Alex: } & \begin{array}{l}\text { Michael ... [He starts acting out a fist fight, pre- } \\ \text { tending he is punching an invisible opponent] ... } \\ \text { Yeah Michael. }\end{array} \\ \text { Jason: } & \text { They're white boys ... [The group laughs.] ... They } \\ & \text { get a hard time. } \\ \text { AO: } & \text { What do you think about that? } \\ \text { Daryl: } & \text { It's alright ... (Laugh) ... As long as Pakehas aren't } \\ & \text { trying to take over ... (Laugh) }\end{array}$

Although the indigenous community narrative and the young people's cultural, family and personal identity is involved with their connection with land and sea, they speak of their ownership in cultural rather than legal terms. This is because the indigenous community narrative views cultural ownership as more relevant in binding the present and past community to the land. Therefore, it is not necessarily legal title but cultural ownership that enables the indigenous community and their young people to keep their ties with the land warm and alive. The young people voices reflect the authority that culture ownership imbues within them by naming Pakeha's, foreigners, visitors, holidaymakers, tourists and relocated retired people as 'outsiders'.

Jacob: They're bringing in heaps of different people for that oil drilling.

AO: How many?

Jacob: Heaps. I'm not sure 'cause they have heaps of different bars and stuff and people that use them.

Maryann: Bringing in outsider, more outsider. Like in summer when they come and be painful and that.

The outsider narrative envelops the indigenous community narrative so that it furthers dominant societal group interests. This is done by sidestepping legal or cultural ownership issues in two significant ways. The first way the outsider narrative avoids encountering legal or cultural ownership is by editing indigenous Maori cultural and community narratives. For example, the outsider narrative gives prominence to the physical beauty of the area yet does not speak to the societal and historical context from which the Maori community emerges. By presenting the land, beach, and community as societally and historically unblemished the outsider narrative echoes Schiler's statement, 'Everything that nature achieves is divine' (as cited in Monti, 1987, p. 35). The dominant societal group speaks to discourses of perfec- tion and beautification (Lutz \& Collins, 1993) and only emphasises those community experiences that connect with the young people's rich cultural identity and personal relationship with the land and sea. This is the process of minority/dominant societal group surrogacy at work.

The outsider narrative furthers the dominant societal group agenda by accentuating the area's natural geographic perfection. The unpolluted landscape is framed as a sanctuary of blue ocean, blue sky, green hills and boundless space.

Mahia Peninsula Scenic Reserve has a loop track (3.5 $\mathrm{km}$ ) that wanders through 374 hectares and takes you through one of the best examples of semi coastal forest on the North Island east coast. Tawa and kohekohe forest is varied with stands of nikau, rimu, rewarewa and a fern flanked stream. Mahia Scenic Reserve provides an interesting track through classic coastal native bush. Bush walks take from 10 minutes to three hours. (Council, 2001)

The natural unspoilt essence of the land and fresh smell of ocean waves is framed as promising a life of perfection and purity.

The beach-fringed promontory of Mahia Peninsula juts out into the Pacific Ocean and provides a vast playground for a great variety of activities such as fishing, diving, surfing, gentle walks and is a great place for a family holiday. There's a selection of safe, sandy beaches perfect for swimming and picnics. There are sheltered reefs and rock pool environments to explore and fish from. (Resort, 2001)

The outsider narrative further proliferates the discourse of 'beautification and perfection' by romanticising the young people as the living embodiment of native innocence and perfection. Advertisements on the Internet and tourist brochures (Council, 2001b) display pictures of fit, tanned brown teenagers sporting surf gear coloured pink, tangerine, and fluorescent lime, gathering on the beach and roadsides like untamed wildflowers that burst into full blossom in the hot dry summer heat. The outsider narrative emphasises the young people's innocence by romanticising their daily routine as composed of horse riding and swimming in the ocean with evenings spent hanging out around beach fires, playing guitars and singing under the stars. These suntanned, fit, healthy, happy young Maori people spend their days surrounded by green pastures, white sand and blue water beaches. They live a simple carefree native life in the rural outback. The outsider narrative feeds upon the physical healthy vibrancy of these young people. Yet it avoids their participation in any type of delinquent behaviour lest attention is drawn to current situations of societal injustice between the minority and dominant societal groups. 
The outsider narrative represents the sea and land as unowned and separate entities to the indigenous culture and community. In this way the outsider narrative only presents a surface view with no 'peeling of the onion' (Lutz \& Collins, 1993) or attention to the indigenous community narrative other than to nourish and succour the dominant societal groups' needs. By emphasising the ideal and representing the area and indigenous young people as 'untouched', 'pure' and 'innocent' the outsider narrative ignores scars of colonisation such as land alienation, cultural disintegration and tribal identity fractures. By selecting which minority societal group life experiences it acknowledges, the dominant societal group silences those historical and societal forces that shape the indigenous young people and their Maori community.

By focusing upon the community and the area's natural perfection and beauty, the outsider narrative creates an emotional interest that is used as a point of entry into an indigenous community that is weary from surviving historic and contemporary colonisation processes. By accentuating a representation that is emotionally soothing to the dominant social group, the outsider's narrative benefits socially by exploring the community and area with minimal risk. In this case, the emotionally soothing narrative speaks of untainted beauty and youthful innocence, excluding the 'not so soothing' yet real experiences of the indigenous community narrative. By such exclusion, the dominant societal group commodifies the indigenous community narrative and appropriates societal control and ownership. This means that the dominant societal group uses the notions of beautification and perfection to package the landscape and Maori community as tradable artefacts. In this way the land and community that is culturally owned by the indigenous community is appropriated by the outsider narrative. The outsider narrative represents nothing more than contemporary imperialistic notions of conquest that view green hills, blue sea and brownskinned communities as opportunities for dominant societal group culture or as Smith (1999, p. 97) writes, 'Is this imperialism? No, we are told, this is post-colonialism. This is globalisation. This is economic progress ...' Thus, the theme of natural perfection and beautification speaks to the intangible concepts of power and capitalist imperialism, as an arsenal for the outsider narrative becoming the new frontier of imperialism.

\section{Theme of tranquillity}

The physical setting and natural beauty of the indigenous community narrative presents an aesthetic experience of tranquillity that is reflected in the young people's voices.

Elise: Yeah I like it here, I wish that I never had to leave and they had uni's here and I could just go to school, get my degree and raise my kids here. That would be awesome.
Yet despite the area's tranquillity, the young people are not wrapped in cotton wool against the 'sledge hammer blows' (Green, 1995) of reality. Rural tranquillity is complicated by geographic isolation, rural suffocation and restlessness.

AO: $\quad$ So how would you describe your life here to say ...

Jason: Huh??

AO: What would you say to your younger brothers, sisters, you know, relations?

Alex: That it sucks man. It's hard work out here, nowhere to go from here. Have to leave to get somewhere and it's hard work. No options man.

Danielle: Yeah no opportunities for us.

The young people grow up enduring drug and alcohol abuse, domestic violence and all too frequently chose death rather then life. Their familiarity with this type of pain and loss is reflected by the eerie ease with which they discuss suicide.

Danielle: What do you guys think about suicide?

Jason: Stupid. Depends on the parents, what they taught their kids. How they brought them up, suicide?

Daryl: That's like drugs and all that aye?

Jason: And their minds get all messed up and all confused.

Alex: $\quad$ Or it can be like if you can't handle it. Like if you've got lots of problems, like bills and all that, your kids, someone might of died. They see no other way out of it, just give in, no one to talk too. The easiest way out is just to um ... kill yourself.

AO: We all know people that have done themselves right?

Jason: Yeap ... yeap ... yeah. Daryl's bro.

Daryl: (Daryl is slouching in his chair and not paying attention. When he hears his name he sits up and looks around.) ... Orh aye? ... (The group laughs.)

Jason: Al bay, come on it's your brother man ... (Laugh) ... al bay.

Daryl: Orh yeah he hung himself.

Jason: Al bay you're too much. (The group laughs.)

The complex emotional reality of the indigenous community narrative does not meet the needs of the dominant societal group and, therefore, the outsider narrative silences these experiences. The outsider narrative purports the area's tranquillity as a blueprint for the total rural experience. The area (Mahia) is described in tourist brochures as a fishing, surfing and boating heaven and having stunning scenery besides (Dobsen \& Spence, 2001). Advertisement captions tout Mahia as seclusion at its best: one man, his surfcaster and the sparkling Pacific playground (Dobsen \& Spence, 2001). These captions are accompanied by an illustration of a lone surf caster silhouetted against the blue sea and horizon. These outsider narratives connect emotions of peace and relaxation to particular geographical features of the indigenous com- 
munity narrative so that the community and culture read as nonthreatening and welcoming.

The outsider narrative furthers its influence by speaking in a discourse that appeals to both outsider and indigenous communities. The outsider narrative appeals to the dominant societal group by presenting Mahia as steeped in tradition, invoking feelings of security in a world of economic instability and emotional insecurity. This discourse encourages the outsider adult generation to move from the urban cities to the rural countryside. As I watch their urban to rural drift, I see a yearning in the outsider eyes. I sense that they are looking for a community where they will find a clean slate, the once in a lifetime opportunity to be born again. I see the outsider seeking the rural peace from my community that their global imperialist culture has destroyed and will continue to destroy.

By praising the natural beauty of the area, Maori culture, and people, the outsider narrative speaks a discourse of yearning that attracts other outsiders. This essentially destabilises the cultural ownership that preserves the tranquilly they seek. In this way the outsider narrative props itself up on the indigenous community narrative by producing a sense of nostalgia and reconciliation with the past. One may say it is a returning 'back to the good old times' or to use Rosaldo's (1989) term a sense of 'imperialist nostalgia'. Lutz and Collins (1993, p. 97) explain imperialist nostalgia as, 'mourning the passing of what we ourselves have destroyed'. Thus, the outsider narrative presents the indigenous community as an embodiment of 'New Zealand the way it used to be'.

Another way that the outsider narrative furthers its dominance is by using the discourse of yearning to draw the young people away from their indigenous community and into the urban cities. This is done by first presenting urban cities as the solution to their financial and economic insecurity and then by framing the urban as more desirable than the rural. The young people readily embrace this discourse of yearning and all that the urban lifestyles purport. They speak of the day when they will leave the rural behind them in the following ways.
AO: $\quad$ So tell me about your guys goals for life.
Rodney: Get out of Mahia. (Laugh.)
AO: What did you say?
Rodney: Orh get out of Mahia and go somewhere else, that's one.
Group chorus: Yeah get out of Mahia.
Rodney: You go nowhere if you stay here.

Their talk expresses a rural exodus with which our indigenous community is familiar. I recall my childhood summers where we fumbled with understanding, witnessing and living through the rural to urban drift, with uncles, aunties, and soul mate cousins, leaving home to disappear into what Witi Ihimaera (1972) describes as the 'Emerald city'. They left to be swallowed by a different life where cars, houses, schools and shops were all bigger then our world. 'Big' was a word of distinction. Although we considered our place in the world to be of some unexplained significance, we intuitively knew that accompanying our intrinsic value was a world that viewed us as minutely small. This unspoken societal evaluation shaped our world view so that we involuntarily devalued what we had. Our relationship with the community, land and sea became common and undesirable. Watching our whanau leave in pursuit of what urban life offered solidified that perspective.

Listening to the young people's voices frame the urban lifestyle as a way out of the cultures of depression (Rathbone, 1998) that they associate with their rural location and minority societal group status is like hearing an old familiar song played over and over again.

AO: What do you think of all the whanau that's gone over to Sydney?

Toni: Choice, at least they're getting somewhere.

Rodney: If they stay here they do nothing, they just bum around. I say go.

Quincy: Yeah they just bum around.

Toni: I'm gona work there.

AO: What do you think of those guys?

Rodney: I reckon good on em. Stuff living in Mahia. Gag. Better than some of us round here.

AO: Why's that?

Quincy: Stay here you get nothing. Stay here you just bum around.

The young people are torn between the familiar securities that the indigenous community narrative offers on the one hand and all that the dominant societal group's urban life style promises on the other.

Quincy: I'm taking off to Aussie, that's what I'm doing.

Toni: I am too, lets go to Aussie.

(Quincy raises his eyebrows in agreement with the Aussie idea. Quincy and Rodney both laugh at each other.)

Quincy: Go to Aussie mate. Somewhere out of Mahia anyway.

Maryann: I'll miss my friends but.

Quincy: Stay here you'll just end up unemployed and hapu.

Maryann: I'm not staying here. I'm just saying I'll miss it.

Quincy: You can always come back and visit, but I'm not staying here. I'm gone.

Rodney: That's us bay, were gone.

Although the outsider narrative represents itself as a shelter in the socio-economic storm that the young people are fleeing from, the dominant societal group remains solely vested in pursuing its own interests. This is evidenced by the way the outsider narrative first sani- 
tises the indigenous community narratives that do not fit the discourse of tranquillity and second by the way that the outsider narrative encourages the young people to view the urban lifestyle of the dominant societal group as a solution to their desires for societal and economic stability.

\section{Theme of geographical isolation}

The indigenous community narrative reflects the reality of lives that are largely lived out in geographic isolation.

Karen: I like it because there are no traffic lights. In the city there are lots of people and traffic lights. Here there are only sheep ... (laugh) ... sheep don't use traffic lights.

Louise: Orh you're silly. We don't need that stuff out here, cause there's not that many people and we know everyone anyways.

Karen: It's just us out here.

The outsider narrative associates this geographical isolation with the 'undiscovered last rural frontier' (Lutz and Collins, 1993). They write: 'there appear to be only two worlds the traditional and the modern; the world before 'the west' and its technological and societal progress came to 'the rest' and the world after' (Lutz \& Collins, 1993, p. 110). The outsider narrative epitomises the traditional and modern worlds that Lutz and Collins refer to by combining rural traditions with isolation to create a juxtaposed scenario of 'wilderness' and 'contemporary westernisation'. For example, common community features such as roads, farms and nineteenth century styled homesteads are framed to represent the traditional rural lifestyle. The outsider narrative uses these everyday features to heighten the sense of romanticism by exaggerating the rough and tough rural underside of community life. Roads are represented as risky one-lane metal tracks that due to landslides and rainstorms become inaccessible in winter. Farm homesteads become points of human warmth and contact. The primary school that dates back to the early 1900s Native Schooling system is represented as a quaint historical feature from the early pioneering days. The school bus route converts into a narrative of endurance with children travelling across hazardous farm terrain despite stormy weather to meet the bus. The one hour drive to the nearest medical centre is romanticised by focusing on the heroic feats of the emergency helicopter service that rescues critically sick and injured community people. Coastal lighthouses that provide safe passage for ships navigating the rugged coastline appear on local and national post cards as the epitome of a past age of chivalry. The local township is portrayed as a reminiscent sleepy hollow village nestled among the surrounding hills servicing the farming hinterland with farming equipment, banks, and grocery and clothing shops.

Thus the outsider narrative accentuates the geographically isolated elements by presenting the rural experience as extraordinarily rare. This means that the community becomes an easy target for dominant societal group fantasy, imaginations and sensationalism. The young people encounter these outsider narrative ideologies with cynicism and laughter.
Jacob: Yeah but bro you should see some of the things they ask us! (The group laughs.)
AO: Like what?
Jacob: It's like they think we don't have TV or any idea about the outside world. (Laugh.)
Toni: Yeah but we know more about their white faced world than they know about ours. It's like every- body wants to know if I have my own horse. Like I ride a horse now! Man I've got other stuff to do and hellooo ... we drive cars nowadays people!

Maryann: Orh you still ride a horse, that's how come your hand is hurt. Sliding on your horse, don't be acting like you're all cool when you still ride. (Maryann starts laughing at Toni.)

Quincy: Like you remember how Eric brought everything cause ... (Laugh) ... Bro he thought he'd be washing in the river or something cause we wouldn't have power. (The group laughs.)

Jacob: Man that's rude aye! That's like how you see honkie's washing in the sea down by the camp. We don't go to their place and jump in their pool and have a wash man.

The frustrating insults that the young people voice stem from the outsider narrative misrepresenting the indigenous community as living a life different from that of the dominant societal group's everyday experience. The outsider narrative does this because at a day-to-day level it is dependent upon maintaining separate minority and dominant societal group identities. In order to maintain its separate status the outsider narrative silences or misrepresents minority and dominant societal group similarities. This is illustrated by the way they erase the similarities that exist between minority and dominant societal group young people. For example, one homogeneous feature of New Zealand youth culture is their need to explore and challenge cultural, societal and geographical barriers.

Danielle: Out here the ones that don't go to school just go surfing and on the dole ... They hardly do anything and the ones that are on the dole or who are trying to find work, um, well there's nothing really out here for them. And most of the young group is about sixteen to twenty, twenty one or something are just out here surfing and having a good time.

AO: What does 'nothing out here' mean?

Danielle: We need something out here for the youth. There was a karate club and a rock n' roll club but that fizzled out after a few years. All the youth out here they just go surfing ... just bum around. And when their not surfing they are out fishing.

AO: $\quad$ Do you're mates in town get bored? 
Jason: Yeah cause, it's like they get bored with town and think that we are lucky have beaches and horses to ride but we're thinking they are lucky living in town. I guess that we just don't know how lucky we are.

The indigenous young people's voiced boredom and dissatisfaction reduce the societal differences between minority and dominant societal groups by accentuating the commonality that exists. These commonalities humanise the minority societal group and contradict the outsider narrative portrayal of the indigenous community living a wild rural frontier lifestyle.

\section{Theme of Individual Isolation}

Accompanying the geographical isolation is the isolation of the self. The indigenous community narrative acknowledges that individual isolation exits but like geographical isolation it does not sensationalise this feature. The indigenous community views the rural as filled with the history of their past and present families. The young people voices reflect a communion with whanau, hapu and iwi.

Alex: You know at home I'm always getting something to do. If I'm going to the shop it's like I have to call in at everyone's place to see if they want something. It's a bit of a pain you know, and than there is always something on at Kaiuku (Kaiuku is one of the five marae on the peninsula) so we've always go to go there and work. I usually take off on the cars.

Danielle: I think some people might see it as lonely but they don't live here and there's always something on. Even if we see each other in the city it's the same, what I have is yours and what you have is mine.

Loneliness is a feature that the young people do not associate with their rural existence but with their urban experiences. For example, three young people have moved with their family to the city so as they are closer to secondary and tertiary education facilities. The following talk portrays how they view their urban societal relationships,

Danielle: You don't even know your next door neighbours, right. They like to look after themselves.

Daryl: Yeah we don't even know our neighbours cept for our Somalian ones. (Laugh.)

Daryl: What's his name?

Danielle: Fred. Townies like to look after themselves.

The outsider narrative hitchhikes upon the indigenous community narrative by projecting the rural as divorced from social interaction. The ideological notion of individual isolation appeals to the dominant societal group as it symbolises a healing balm for societal weariness. Nash points out that nature represents a spiritual domain in which civilisation's ills can be cured (Nash, 1982). He speaks of the regeneration that the dominant societal group hopes to find through rural bliss and the solace of one's own company. Once again the outsider narrative adjusts the essence of the indigenous community narrative so that it is host to dominant societal group ideals.

\section{Theme of traditional farming industry}

The farming industry is a vital part of the indigenous community narrative and in shaping the young people's lives:

Hugh: Well out here most people farm. My dad he works on the farm and rides a motor bike. I try not to go with him as he goes away all day and I get really bored.

Tamara: Mahia is a beautiful place by the sea only just that most jobs are farming or fishing and I don't want to do that so I will leave here after I'm twenty-one and go to the city.

The outsider narrative idealisation of farming ignores Maori land alienation and focuses upon the 'native being a good worker' (Gilman, 1985). The outsider narrative uses the indigenous community narrative of farming first to provide the nation's rural identity, and then to give the national economy a sense of tradition and stability. The area is presented as a rural farming ideal. Wilson (1978) gives the history of this approach. During the Victorian era, a small number of British born 'country gentlemen' owned considerable amounts of Wairoa land. They had acquired land from either the Maori owner or the Government. They considered themselves the unquestionable masters of the districts.

The indigenous community young people voice the historic and current colonisation of their land in the following ways:

Jessica: We used to own that land but my mother says we lost it to the pakeha.

Jacob: Bro we all lost our land and that's one more reason to not stay here.

Quincy: Yeah we'll only get bum jobs here now.

The following slices of voice illustrate the young people's search for future employment and their porousness to both minority and dominant discourses. For example, the young people know the job opportunities that the farming industry offers and do not like them.

Jason: There's no jobs, no opportunities.

Alex: No jobs.

AO: What about fencing and shearing.

Amy: Farming?

Danielle: Those don't last.

Alex: Those only last, those are only seasonal jobs.

Danielle: Those only last while your bodies still young.

AO: Don't you want to do those?

Alex: Orw nah, only old people do that.

Daryl: Only rough people do that. 
Amy: You have to have the right back for shearing, to do that.

Danielle: And you've got to have the right knowledge for fencing.

AO: Do you think those are skilled jobs?

Alex: Nah just hard work.

Jason: Orw nah.

Danielle: Hard labour.

Alex: They say that you can do better work with your mind than with you hands.

AO: What do you think about working at Waitaki?

Danielle: Which works? The meat works? AFFCO? Orh nah.

Alex: Nah machines come in

Jason: Nah, if you get laid off and then you have nothing to fall back on.

Although the young people's parents have supported their families through farm labourer jobs they do not wish their futures to be patterned after their example. Therefore, although farming is a large part of their indigenous community the young people worry about how their location within an isolated rural farming community limits their employment opportunities.

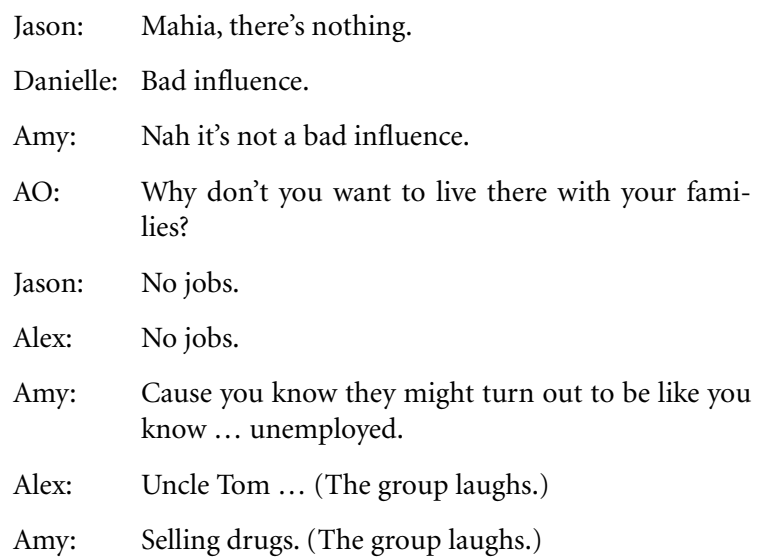

The young people voices illustrate two things. First, it draws attention to the disparity between the indigenous community and outsider narratives. Second, it illustrates how they acknowledge farming as part of their societal and cultural identity, yet they have the need to relocate to cities in search of educational and employment opportunity. The move is something they view as inevitable if they are to survive economically.

Quincy: We'll always remember this place. Wolly still comes back from Sydney to see the folks.

Jacob: Yeah it's like you can't live through what we know, you know like see what we've seen and not come back.

Their association of rural farming life with hard labour and future unemployment reinforces their yearning for the urbanised dominant societal group lifestyle and their eventual community exodus.

\section{Theme of cultural exoticness}

The indigenous community Maori culture is a significant component of the indigenous community narrative and the young people's identity. The indigenous community narrative evolves from the historic context of land loss and grievances. Within the safety of each other's company the young people speak freely about their cultural identity, experiences of societal injustice and ethnic racism.

Karen: I like being a Maori because you can go back and there's lots of history to the word Maori and to the land and I love living in Mahia because there's heaps of Maori instead of Pakeha telling you what to do. I love being around my own people, I'm having fun with my own kind instead of Japanese and pakeha's.

Andy: I like being Maori cause there's a lot of history about it. Pakeha's they think, they are just real arrogant and they always try to screw the Maori territory.

Karen: There are some good ones.

Andy: I like being a Maori cause it makes me feel stronger and the word reminds me of just mana and it makes me feel good. I like being a Maori cause Pakeha are just stuck up and think they can rule us Maoris and we have to stand for our rights.

Because the indigenous community narrative evolves from a historic political struggle the young people are aware that even though they desire the financial security of the dominant societal group it is they who oppress them.

Veronica: The Government yeah, it's not fair over the land and cause it's um ... Pakeha's think that Maori can be real arrogant and yeah.

Andy: Pakeha's aren't that fair to the Maori. The government aren't that fair to Maori cause of like, with the land. They build hotels and big magic thingy's and they want to make their life on some else's property and they build their houses with no permission and Pakeha think that Maori are thick and they're not, sometimes they're more cleverer then the Pakeha.

Karen: Not all Pakeha's think they're cool, and they're cool, I don't really know about it.

Andy: It's cause Maori are a darker colour.

The outsider narrative bypasses the young people's political history and commodifies the indigenous Maori culture as the 'exotic other'. Sutherland (1940) writes that the Maori are too easily expected to be picturesque and the romantic New Zealand. This is illustrated by the way the outsider narrative slices up the indigenous community traditional Maori legends, or Maori tanga, to intrigue dominant societal group individuals or outsiders with 'sacred and formally organised behaviour' (Lutz \& Collins, 1993, p. 95).

An Internet advertisement (Parkinson \& Malone, 1998) illustrates how the outsider narrative misuses the indigenous community local legends. In discussing the relationship of Maori to the whale, the advertisement 
describes the promontory of Mahia that serves as a natural whale trap. The capture of a whale meant a good supply of food for the Maori, and they called the area a 'mauri' something that attracted whales ashore.

This story combines three legends into one, misconstrues place names and historic cultural information and is an abortion of Rongomaiwahine tribal history. Gilman (1985) writes about the process that the dominant societal group uses in creating the exotic other, balancing the story so as to make the exotic attractive and desirable. The creation of an exotic involves a balance between the exotic and humanism. The outsider narrative exonerates this process by portraying Maori culture as an exotic spectacle while simultaneously focusing upon common human elements in an attempt to not alienate the 'other' into an unreachable world of difference. The exotic involves 'the creation of an other who is strange but - at least as important — beautiful' (Lutz \& Collins, 1993, p. 95). By creating the exotic other, the outsider narrative fulfils the human yearning to discover, 'an ideal world, free of suffering' (Lutz \& Collins, 1993, p. 95).

This is graphically portrayed by the history of another east coast iwi, Ngai Tamanuhiri. They disputed the possible sale of 'Te Kuri A Paoa', known for its 600 foot high white cliffed headland, to a foreign ownership. Te Kuri A Paoa is significant to Ngai Tamanuhiri because it was sighted by Paoa, the captain of the Horouta waka who used it as a landing place. When a child is born they bury the placenta and umbilical cord at the top of the cliffs keeping the relationship between land and iwi alive.

Ngai Tamanuhiri petitioned the Government to reconsider selling the site to a US millionaire, John Griffin. Ngai Tamanuhiri sought and received court injunctions; offered to buy 200 hectares of the headland to protect their $\mathrm{Pa}$ and waahi tapu; they commmunicated their iwi concerns to the US-buyer John Griffin but received little response; and finally they resorted to occupying the land that they viewed as culturally theirs. They appealed to the nation for support and were buoyed up by Pakeha, politicians and fellow Maori. After months of negotiation, Finance Minister Michael Cullen announced the final sale with the assurance that John Griffin would gift the historic parts of the site to the Government and would form a trust with Ngai Tamanuhiri to give them their cultural access. Ngai Tamanuhiri are resigned to the land passing into foreign ownership but as one iwi member expressed it: 'we are forever hopeful that one day we will get our cliffs back.' The sale of 'Te Kuri A Paoa' into foreign ownership reads as a narrative of marginilisation. Tutekawa Wyllie, a Ngai Tamanuhiri spokes man, said that he felt as though they had been railroaded. (Mills, 2002)

John Griffin said he had fallen in love with New Zealand and wanted to have some coastal land (Brown, 2002). The New Zealand Government supports such global elitism that searches the world hunting out ideal spots of exotic beauty. Roger Kerr executive director of the New Zealand Business Roundtable is described by Brown (2002) has having expressed the dominant societal group view that New Zealand does not have restrictive arrangements on foreign investments and is open for business. (Brown, 2002).

Unfortunately this particular business deal does not mention the care and protection that the land receives from an indigenous Maori community. Such oversights fracture indigenous Maori tribal history and traditions. For example, the sale of 'Te Kuri A Paoa' into foreign ownership separates the Ngai Tamanuhiri from their waahi tapu and $\mathrm{Pa}$ sites. It also places their access route to traditional fishing grounds and seafood sites into question. The 'kai tiaki' relationship between the indigenous community and land is disembodied so that the land and iwi are isolated from that which gives them life and meaning. The indigenous community narrative is silenced so that the indigenous Maori community bears the burden of defending their Maori cultural traditions to national and global society.

\section{Summary}

The societal relationship that exists between the dominant and minority societal groups of New Zealand should not be seen as one in which the marginalised minority societal group is a powerless victim of the dominant societal group. Rather, societal groups are positioned within dynamic relationships of power that shape the ways that the minority group is able to engage with society. This is illustrated by showing how the dominant societal group silences the indigenous community experiences in particular ways that progress the dominant societal group agenda, while subjugating the minority societal group societal and cultural knowledge. Minority societal group marginalisation is addressed at a collective indigenous community level and also in reference to the indigenous community young people. Further, the way in which the young people's cultural and societal identity is flavoured by local, national and global cultures is discussed. Their experience of marginalisation speaks to sites of complex struggle, which they articulate by weaving dominant and minority discourses together. Although this is paper has largely spoken to their experiences of marginalisation in New Zealand, their experience is transferable to any number of national and international minority societal groups and indigenous communities. That alone is telling evidence of the crisis situation.

\section{References}

Brown, C. (2002). It reminds them of California: Goodbye NZ!, 2002. Retrieved from http://portland.indymedia.org/ en/2003/10/273887.shtml 
Council, W.D. (2001a). Wairoa district highlights, 2003. Retrieved from http://www.eastland.tourism.co.nz/ wairoa_highlights.html

Council, W.D. (2001b). Wairoa: New Zealand the way it used to be. Wairoa: New Zealand the way it used to be, 19.

Dobsen, D., \& Spence, M. (2001). Discover a whole new paradise. A supplement of the Gisborne Herald. Gisborne and the East Coast: Discover, 15.

Fine, M. (1994). Dis-stance and other Stances: Negotiations of power inside feminist research. In M.W. Apple (Ed.), Power and method. Political activism and educational research (pp. 13-35). New York: Routledge.

Gilman, S. (1985). Difference and pathology: Stereotypes of sexuality, race and madness. Ithaca: Cornell University Press.

Ihimaera, W. (1972). Pounamu pounamu. Auckland, New Zealand: Heinemann Education.

Lutz, C., \& Collins, J.L. (1993). Reading National Geographic. Chicago: University of Chicago.

Mills, L. (2002). Ngai Tamanuhiri to file court injunction. Gisborne Herald, p. A9.

Monti, N. (1987). Africa then: Photographs, 1840-1918. New York: Knopf.

Morrison, T. (1993). Playing in the dark. New York: Random House.

Nash, R. (1982). Wilderness and the American mind. New Haven: Yale University Press.

Novick, M. (1995). White lies white power: The fight against white supremacy and reactionary violence. Common Courage Press.

Parkinson, B., \& Malone, J. (1998). Unique wild life of New Zealand. Retrieved November, 25, 2003, from http:// www.ecotours.co.nz/Brian/wildlife/hawkesbay/mahia.htm

Rathbone, C. (1998). On the outside looking in: A year in an inner-city high school (1st ed.). New York: Atlantic Monthly Press.

Resort, B. B. H. (2001). Blue Bay Holiday Resort, 2001. Retrieved from http://www.bluebay.co.nz/

Rosaldo, R. (1989). Culture and truth. Boston: Beacon Press.

Smith, L. T. (1999). Decolonizing methodologies: Research and indigenous. Dunedin, New Zealand: University of Otago Press.

Smith, L.T., Boler, M., Smith, G.H., Kempton, M., Ormond, A., Chueh, H., et al. (2002). 'Do you guys hate Aucklanders too?' Youth: voicing difference from the rural heartland. Journal of Rural Studies, 18 [Special Issue: Young Rural Lives], 169-178.
Snow, D. (1993). Community in aboriginal notion.

Sutherland, I. L. G. (1940). The Maori people today. Whitcombe \& Tombs.

Wilson, R. C. (1978). Wairoa County Council: The first hundred years. Wairoa Hawke's Bay, New Zealand: Kerslake Billens \& Humphrey.

\section{Glossary}

AFFCO One of the local abattoirs. This abattoir is a source of seasonal employment for the indigenous community.

Aussie Abbreviation for the country Australia.

Bay A term the young people use to refer to each other instead of referring to each other's name. They also use this term with the prefix 'Al' so that it also appears as 'al bay'.

$\mathrm{Fa}$ Abbreviation for 'far out'. It is used in reference to the uniqueness of a situation,

context or conversation.

Нари Maori word for pregnant.

Hellooo Colloquial term the young people use when they are questioning the reality or sanity of a situation or person.

Honkie Colloquial term that the young people use to refer to Pakeha or people that are fair skinned.

Iwi. Maori word meaning 'tribe'.

Kina Type of sea urchin that is a particular Maori delicacy.

Losties Plural for lost. The young women use it when individuals have lost their ability to reason.

Mahiasian A name that indigenous community individuals use in reference to those indigenous community members that are born, bred and loyal to Mahia.

Mana Maori term used to refer to power and independent strength.

Maori tanga Maori cultural lore.

Sydney Sydney, Australia. Many of our whanau have moved to Sydney in order to find employment in mining companies. These whanau now encourage younger relations to follow their lead and find mining jobs in Australia.

Tight Colloquial slang used to describe someone that does not share or is selfish.

Townies. Colloquial slang that refers to people that live in urban towns.

Unis. Abbreviation for Universities.

Waitaki The local abattoir. This abattoir is a source of seasonal employment for the indigenous community.

Whanau Maori word that means 'extended family'. 